\title{
Pulmonary Hypertension Induced by Thalidomide (and Derivatives) in Patients with Multiple Myeloma: A Systematic Review
}

\author{
Abdulqadir J. Nashwan",2*, Nader I. Al-Dewik ${ }^{3,4,5}$, Hisham M. Al Sabah', Mohamed A. Yassin', \\ Shehab F. Mohamed6, Nabil H. Omar7, Dana B. Mansour ${ }^{8}$ \\ ${ }^{1}$ National Center for Cancer Care \& Research (NCCCR)-Hamad Medical Corporation, Doha, Qatar, \\ ${ }^{2}$ University of Calgary, Doha, Qatar \\ ${ }^{3}$ Qatar Medical Genetics Center, Hamad General Hospital (HGH), Hamad Medical Corporation (HMC), Doha, Qatar \\ ${ }^{4}$ Interim Translational Research Institute (iTRI), HMC, Doha, Qatar \\ ${ }^{5}$ Faculty of Health and Social Care Sciences, Kingston University and St George's University of London, London, United Kingdom \\ ${ }^{6}$ Medical Oncology/Hematology Department, National Center for Cancer Care and Research, Hamad Medical Corporation, Doha, Qatar \\ ${ }^{7}$ National Center for Cancer Care \& Research (NCCCR)-Hamad Medical Corporation, Doha, Qatar \\ ${ }^{8}$ Qatar Cancer Society, Doha, Qatar \\ Email: ^Anashwan@hamad.qa, Naldewik@hamad.qa,Hsabah@hamad.qa, Yassin@hamad.qa,Smohamed22@hamad.qa, \\ Nomar4@hamad.qa, Dana.basem@gmail.com
}

How to cite this paper: Nashwan, A.J., Al-Dewik, N.I., Al Sabah, H.M., Yassin, M.A., Mohamed, S.F., Omar, N.H. and Mansour, D.B. (2016) Pulmonary Hypertension Induced by Thalidomide (and Derivatives) in Patients with Multiple Myeloma: A Systematic Review. Journal of Cancer Therapy, 7, 971-978.

http://dx.doi.org/10.4236/jct.2016.713094

Received: October 19, 2016

Accepted: November 30, 2016

Published: December 2, 2016

Copyright $\odot 2016$ by authors and Scientific Research Publishing Inc. This work is licensed under the Creative Commons Attribution International License (CC BY 4.0).

http://creativecommons.org/licenses/by/4.0/

(c) (i) Open Access

\section{Abstract}

Thalidomide is widely used in the treatment of multiple myeloma (MM). In recent years, several cases of pulmonary hypertension have been reported following treatment with thalidomide. The aim of this review was to evaluate the published literature on multiple myeloma patients with pulmonary hypertension following thalidomide treatment. A literature search was performed between 2000 and 2016 . A total of 7 eligible studies were identified and deemed eligible, including 11 cases-approximately 37\% (4 cases) with IgA (k), 27\% (3 cases) with $\operatorname{IgG}(\lambda) \mathrm{MM}$, $27 \%$ (3 cases) with IgG (k) MM, and one case (9\%) with primary plasma cell leukemia (PPCL). The vast majority of cases-82\% (9 cases) - are associated with thalidomide, while only $18 \%$ (2 cases) are related to thalidomide derivatives (lenalidomide and pomalidomide). In conclusion, pulmonary hypertension induced by thalidomide or derivatives in multiple myeloma (MM) patients is related to a multifactorial etiology including the pathophysiology of the disease, thromboembolic events, preexisted cardiovascular conditions, comorbidities, and combination with other chemo- or bio-therapeutic agents. MM patients should be evaluated for signs and symptoms underlying cardiopulmonary disease before initiating, and during treatment with thalidomide. 


\section{Keywords}

Thalidomide, Thalidomide Derivatives, Pulmonary Hypertension, Multiple Myeloma

\section{Introduction}

Multiple myeloma (MM) is thrombogenic as a consequence of multiple hemostatic effects, including elevated interleukin- 6 levels, procoagulant antibody formation, paraprotein interference with fibrin structure, activated protein $\mathrm{C}$ resistance, and endothelial damage [1] [2].

$\mathrm{MM}$ is a treatable, mature B-cell malignancy, which accounts for approximately $10 \%$ of the hematologic malignant neoplasms, and progress in improving survival has been rapid in recent years [3] [4] [5].

Thalidomide is active in both newly diagnosed [6] [7] [8] [9] [10] and advanced MM, and as first-line therapy in combination with dexamethasone or other cytotoxic chemotherapy [11] [12] [13]. Its mode of action includes direct apoptotic, antiangiogenic effects, and modulation of the bone-marrow microenvironment [14] [15]. However, the exact mechanism of action of thalidomide has not yet been clearly explained [16] [17].

Thalidomide has been linked with an increased risk of thromboembolic events (TEEs), including pulmonary hypertension (PH) and venous thromboembolism (VTE) [18] [19] [20]. The underlying cause of this VTE remains unclear, although several mechanisms have been postulated. It is well known that VTE can lead to PH [21].

Pulmonary hypertension is defined by a mean pulmonary artery pressure $\geq 25 \mathrm{~mm}$ $\mathrm{Hg}$ at rest, measured during right-side heart catheterization. The term pulmonary arterial hypertension $(\mathrm{PAH})$ describes a subpopulation of patients with $\mathrm{PH}$ characterized hemodynamically by the presence of pre-capillary $\mathrm{PH}$ including an end-expiratory pulmonary artery wedge pressure (PAWP) $\leq 15 \mathrm{~mm} \mathrm{Hg}$ and a pulmonary vascular resistance $>3$ Wood units [22].

Pulmonary hypertension was previously classified into two categories (primary and secondary) according to the presence of identified etiology. In 1998, a clinical classification was established to personalize different classes of $\mathrm{PH}$ sharing similar pathological findings, hemodynamic characteristics, and management. Five groups were identified: pulmonary arterial hypertension (Group 1); $\mathrm{PH}$ due to left-side heart disease (Group 2); PH due to chronic lung disease and/or hypoxia (Group 3); chronic thromboembolic PH (Group 4); and PH due to unclear multifactorial mechanisms (Group 5) [23].

Clinical signs include fatigue, dyspnea, dizziness, leg swelling, and chest tightness. It often progresses to right-side heart failure, which might be due to cardiac amyloidosis (CA) [24].

\section{Study Objective and Significance}

There has been a limited amount of research focusing on the link between thalidomide 
and the development of pulmonary hypertension. The findings of this review will provide more knowledge about one of the adverse events following thalidomide treatment. The aim of this review was to evaluate the published literature on multiple myeloma patients with pulmonary hypertension following thalidomide treatment.

\section{Materials and Methods}

\section{Search Strategy and Eligibility Criteria}

A literature search was conducted using various databases-including PubMed, ScienceDirect, and Google Scholar-for articles published between 2000 and August 1, 2016. The following keywords: (thalidomide), (thalidomide derivatives), (lenalidomide), (pomalidomide), (pulmonary hypertension), (pulmonary arterial hypertension), and (multiple myeloma) were entered, and the search was limited to articles in English describing the association between thalidomide and thalidomide derivatives and the development of pulmonary hypertension in patients with different types of multiple myeloma. The resulting abstracts were screened, and only full-text articles published in peer-reviewed journals were retrieved for review. Reference lists were also searched to find further eligible articles. Particular attention was taken to ensure that each study was represented only once.

\section{Results}

\subsection{Publications Search}

A total of 7 eligible studies were identified and deemed eligible: case reports (6) and a pilot study (1) published between 2003 and 2015. One study was excluded because the patient was diagnosed with Angiodysplasia, and the article was published in Spanish [25] (Table 1).

\subsection{Patient Characteristics}

Only 11 cases of MM with pulmonary hypertension following thalidomide (and derivatives) treatment have thus far been reported: age ranges from 51 to 79 years (mean = 67.5). With regard to gender: five males (46\%), 4 (36\%) females, and $2(18 \%)$ with (not available) gender. Approximately $37 \%$ ( 4 cases) with $\operatorname{IgA}(\mathrm{k}), 27 \%$ (3 cases) with $\operatorname{IgG}(\lambda)$ MM, 27\% (3 cases) with IgG (k) MM, and one case (9\%) with primary plasma cell leukemia (PPCL). The vast majority of cases $82 \%$ (9 cases) are associated with thalidomide, while only $18 \%$ ( 2 cases) are related to thalidomide derivatives (lenalidomide and pomalidomide). On the other hand, the described doses varied from $50 \mathrm{mg} / \mathrm{d}$ to 400 $\mathrm{mg} / \mathrm{d}$ for thalidomide. Most of the patients were presented with dyspnea, peripheral edema, and asthenia, or incidentally discovered following continual follow-up with echocardiography.

\section{Discussion}

The studies differed in several important aspects, including specific diagnosis, age 
Table 1. List of published literature on PH following treatment with Thalidomide (and derivatives).

\begin{tabular}{|c|c|c|c|c|c|c|c|c|}
\hline Author & $\begin{array}{l}\text { No. of } \\
\text { Cases }\end{array}$ & Diagnosis & Drug & Dose & Age (yrs) & Gender & Presentation & RVSP \\
\hline $\begin{array}{l}\text { Younis, } \\
2003 \text { [26] }\end{array}$ & 1 & $\operatorname{IgA}(\mathrm{k}), \mathrm{MM}$ & Thal & $\begin{array}{l}400 \mathrm{mg} / \mathrm{d} \text { then } \\
\text { reduced to } 100 \\
\mathrm{mg} / \mathrm{d} \text { then to } \\
50 \mathrm{mg} / \mathrm{d}\end{array}$ & 51 & M & Peripheral edema & $\begin{array}{l}70 \mathrm{mmHg} \text { (back to } 47 \mathrm{mmHg} \\
\text { after } 2 \text { months of Thal } \\
\text { discontinuation) }\end{array}$ \\
\hline $\begin{array}{l}\text { Hattori et } \\
\text { al., 2005 } \\
{[27]}\end{array}$ & 1 & $\operatorname{IgA}(\mathrm{k}), \mathrm{MM}$ & Thal & $400 \mathrm{mg} / \mathrm{d}$ & 57 & $\mathrm{~F}$ & Mild dyspnea on exertion & NA \\
\hline $\begin{array}{l}\text { Antonioli } \\
\text { et al., } \\
2005[28]\end{array}$ & 1 & $\operatorname{IgG}(\mathrm{k}), \mathrm{MM}$ & Thal & $\begin{array}{l}100 \mathrm{mg} / \mathrm{d} \text { with } \\
\text { increase to } 200 \\
\mathrm{mg} / \mathrm{d}\end{array}$ & 63 & M & $\begin{array}{l}\text { Dizziness, asthenia and } \\
\text { breathlessness }\end{array}$ & $\begin{array}{l}90 \mathrm{mmHg} \text { (reduced to } 60 \mathrm{mmHg} \\
\text { after one month of Thal } \\
\text { discontinuation) }\end{array}$ \\
\hline $\begin{array}{l}\text { Lafaras et } \\
\text { al., } 2008 \\
{[23]}\end{array}$ & 4 & $\begin{array}{l}\operatorname{IgG}(\lambda), \mathrm{MM} \\
\operatorname{IgG}(\mathrm{k}), \mathrm{MM} \\
\operatorname{IgG}(\mathrm{k}), \mathrm{MM} \\
\operatorname{IgG}(\lambda), \mathrm{MM}\end{array}$ & Thal & $200 \mathrm{mg} / \mathrm{d}$ & $\begin{array}{l}59 \\
68 \\
72 \\
76\end{array}$ & $\begin{array}{c}\text { M } \\
\text { F } \\
\text { NA } \\
\text { NA }\end{array}$ & Echocardiogram & $\begin{array}{c}98 \mathrm{mmHg} \\
54 \mathrm{mmHg} \\
\mathrm{NA} \\
\mathrm{NA}\end{array}$ \\
\hline $\begin{array}{l}\text { Tamura et } \\
\text { al., } 2014 \\
{[30]}\end{array}$ & 1 & $\begin{array}{l}\text { Primary } \\
\text { plasma cell } \\
\text { leukemia } \\
(\mathrm{PPCL})^{*}\end{array}$ & $\mathrm{~L}$ & $10 \mathrm{mg} / \mathrm{d}$ & 76 & M & $\begin{array}{l}\text { Leg edema and dyspnea on } \\
\text { exertion }\end{array}$ & Estimated mPAP $59 \mathrm{mmHg}$ \\
\hline $\begin{array}{l}\text { Krishnan } \\
\text { et al., } \\
2015 \text { [31] }\end{array}$ & 2 & $\begin{array}{l}\operatorname{IgA}(\mathrm{k}) \mathrm{MM} \\
\operatorname{IgA}(\mathrm{k}) \mathrm{MM}\end{array}$ & $\begin{array}{l}\text { (L\&P) } \\
\text { Thal }\end{array}$ & NA & $\begin{array}{l}72 \\
69\end{array}$ & $\begin{array}{c}M \\
F\end{array}$ & $\begin{array}{l}\text { Worsening dyspnea } \\
\text { on exertion }\end{array}$ & $\begin{array}{l}83 \mathrm{mmHg} \\
65 \mathrm{mmHg}\end{array}$ \\
\hline
\end{tabular}

${ }^{\star}$ Plasma cell leukemia (PCL), a rare but particularly aggressive form of multiple myeloma (MM), is defined by an absolute count of $2.0 \times 10^{9} / 1$ (or $20 \%$ of peripheral white blood cell count) circulating plasma cells. [26]; NA = Not Available, Thal = Thalidomide, $\mathrm{L}=$ Lenalidomide, $\mathrm{P}=$ Pomalidomide, RVSP $=$ Right Ventricular Systolic Pressure, mPAP = Mean Pulmonary Artery Pressure.

groups, combination protocols, duration of treatment, and the presence of comorbidities-especially thromboembolic events-which made comparisons somehow challenging.

In 2003, Younis [26] reported the first case of possible association between thalidomide and reversible PH in MM. A direct impact of thalidomide on the pulmonary vascular endothelial cells was suggested since a rapid reduction of pulmonary artery pressure after thalidomide interruption was observed.

Likewise, Hattori [27] and colleagues in 2005 also experienced the occurrence of $\mathrm{PH}$ in a MM patient during treatment with thalidomide by reporting the clinical course and autopsy findings. However, they clearly stated that the exact mechanism remains to be revealed; $\mathrm{PH}$ assessment and follow-up should be considered when thalidomide is used for MM patients. On the other hand, an autopsy revealed an extensive formation of plexogenic pulmonary arteries accompanied by the thickening of intimae and media arteries.

Six years later, Antonioli [28] and colleagues reported that one case diagnosed with IIA MM IgG kappa progressed from monoclonal gammopathy of unknown significance (MGUS). The patient was refractory to different chemotherapy regimens. Later, she refused further chemotherapy and autologous transplant, which is the reason why the patient started on thalidomide, $100 \mathrm{mg}$ daily, with a progressive increase to $200 \mathrm{mg}$ 
daily and dexamethasone for seven months without significant side effects. After one year and while on thalidomide, the patient presented to the center with dizziness, asthenia, and dyspnea. Moreover, the findings of this report supported the previous two reports in the need to clarify whether pulmonary hypertension is considered as an adverse effect of thalidomide and how the drug eventually affects the endothelial cells of blood vessels.

In 2008, Lafaras [23] and colleagues conducted the first clinical (pilot) study to detect the clinical and subclinical non-thromboembolic PH in MM patients after thalidomide treatment. The clinical and echocardiographic evaluation revealed four patients (out of 82 patients, 4.87\%) with $\mathrm{PH}$. Non-imaging and imaging diagnostic methods excluded thromboembolic PH. Statistical analysis demonstrated a significant correlation between structural heart disease and $\mathrm{PH}(\mathrm{r}=14.078 ; \mathrm{P}=0.008)$. No significant correlation between age, gender, International Staging System (ISS), and PH was found. Moreover, clinical assessment is essential when initially evaluating patients with suspected $\mathrm{PH}$, but echocardiography is a key screening tool in the diagnostic algorithm to eliminate any secondary causes of $\mathrm{PH}$, predict the prognosis, observe the efficacy of specific therapeutic interventions, and detect the preclinical stage of the disease.

In 2011, Villa [29] and colleagues reported a case of a 79-year-old woman with MM who was started on thalidomide treatment. About a month later, she presented with signs and symptoms of $\mathrm{PH}$. Echocardiography revealed severe $\mathrm{PH}$ without cardiogenic origin, and pulmonary embolism was excluded; a previous echocardiography was normal. Thalidomide was promptly interrupted about a month later; and a physical examination and echocardiography revealed the absence of $\mathrm{PH}$ signs and exhibited normal parameters in both pulmonary artery pressure and right ventricular function.

In 2014, Tamura [30] and colleagues, described a case of a 76-year-old man with primary plasma cell leukemia (PPCL) complicated by renal failure and pulmonary hypertension. Bortezomib/dexamethasone (BD) induction therapy with lenalidomide was administered in association with continuous hemodiafiltration (CHDF). However, the authors described $\mathrm{PH}$ as a complication for the VRD protocol (bortezomib, lenalidomide, and dexamethasone), and not only the thalidomide derivative.

The most recent case report was published in 2015 by Krishnan [31] and colleagues, where three patients with MM developed severe $\mathrm{PH}$. One case was excluded due to the history of cardiac amyloidosis, and no thalidomide or derivatives were initiated. In conclusion, all authors agreed that additional studies are needed to define the incidence, prevalence, prognosis, follow-up, and pathogenesis of $\mathrm{PH}$ in patients with different types of $\mathrm{MM}$-especially for patients on thalidomide or thalidomide-derivative treatment. Further clinical trials will be needed to confirm the association between thalidomide (and derivatives) with $\mathrm{PH}$ in MM patients, as well as looking to the genetic predisposition for different MM mutations.

\section{Conflict of Interest}

The authors state that they have no conflict of interest. 


\section{Acknowledgements}

This research received no specific grant from any funding agency in the public, commercial, or not-for-profit sectors.

\section{References}

[1] McLaughlin, V.V. and McGoon, M.D. (2006) Pulmonary Arterial Hypertension. Circulation, 114, 1417-1431. https://doi.org/10.1161/CIRCULATIONAHA.104.503540

[2] Yuan, J.X.L. and Rubin, L.J. (2005) Pathogenesis of Pulmonary Arterial Hypertension: The Need for Multiple Hits. Circulation, 111, 534-538.

https://doi.org/10.1161/01.CIR.0000156326.48823.55

[3] Egan, J.B., Shi, C.X., Tembe, W., Christoforides, A., Kurdoglu, A., Sinari, S., et al. (2012) Whole-Genome Sequencing of Multiple Myeloma from Diagnosis to Plasma Cell Leukemia Reveals Genomic Initiating Events, Evolution, and Clonal Tides. Blood, 120, 1060-1066. https://doi.org/10.1182/blood-2012-01-405977

[4] Van Marion, A.M., Auwerda, J.J.A., Lisman, T., Sonneveld, P., de Maat, M.P., Lokhorst, H.M., et al. (2008) Prospective Evaluation of Coagulopathy in Multiple Myeloma Patients before, during and after Various Chemotherapeutic Regimens. Leukemia Research, 32, 1078-1084. https://doi.org/10.1016/j.leukres.2007.12.002

[5] Auwerda, J.J.A., Sonneveld, P., de Maat, M.P. and Leebeek, F.W. (2007) Prothrombotic Coagulation Abnormalities in Patients with Newly Diagnosed Multiple Myeloma. Haematologica, 92, 279-280. https://doi.org/10.3324/haematol.10454

[6] Rajkumar, S.V., Blood, E., Vesole, D., Fonseca, R. and Greipp, P.R. (2006) Phase III Clinical Trial of Thalidomide plus Dexamethasone Compared with Dexamethasone alone in Newly Diagnosed Multiple Myeloma: A Clinical Trial Coordinated by the Eastern Cooperative Oncology Group. Journal of Clinical Oncology, 24, 431-436. https://doi.org/10.1200/JCO.2005.03.0221

[7] Rajkumar, S.V., Rosiñol, L., Hussein, M., Catalano, J., Jedrzejczak, W., Lucy, L., et al. (2008) Multicenter, Randomized, Double-Blind, Placebo-Controlled Study of Thalidomide plus Dexamethasone Compared with Dexamethasone as Initial Therapy for Newly Diagnosed Multiple Myeloma. Journal of Clinical Oncology, 26, 2171-2177.

[8] Hulin, C., Facon, T., Rodon, P., et al. (2009) Efficacy of Melphalan and Prednisone plus Thalidomide in Patients Older than 75 Years with Newly Diagnosed Multiple Myeloma: IFM 01/01 Trial. Journal of Clinical Oncology, 27, 3664-3670. https://doi.org/10.1200/JCO.2008.21.0948

[9] Zervas, K., Mihou, D., Katodritou, E., Pouli, A., Mitsouli, C.H., Anagnostopoulos, A., et al. (2007) VAD-Doxil versus VAD-Doxil plus Thalidomide as Initial Treatment for Multiple Myeloma: Results of a Multicenter Randomized Trial of the Greek Myeloma Study Group. Annals of Oncology, 18, 1369-1375. https://doi.org/10.1093/annonc/mdm178

[10] Palumbo, A., Bringhen, S., Liberati, A.M., Caravita, T., Falcone, A., Callea, V., et al. (2008) Oral Melphalan, Prednisone, and Thalidomide in Elderly Patients with Multiple Myeloma: Updated Results of a Randomized Controlled Trial. Blood, 112, 3107-3114.

https://doi.org/10.1182/blood-2008-04-149427

[11] Glasmacher, A., Hahn, C., Hoffmann, F., Naumann, R., Goldschmidt, H., Lilienfeld-Toal, M., et al. (2006) A Systematic Review of Phase-II Trials of Thalidomide Monotherapy in Patients with Relapsed or Refractory Multiple Myeloma. British Journal of Haematology, 132, 584-593. https://doi.org/10.1111/j.1365-2141.2005.05914.x

[12] Prince, H.M., Schenkel, B. and Mileshkin, L. (2007) An Analysis of Clinical Trials Assessing 
the Efficacy and Safety of Single-Agent Thalidomide in Patients with Relapsed or Refractory Multiple Myeloma. Leukemia \& Lymphoma, 48, 46-55. https://doi.org/10.1080/10428190601001904

[13] Morgan, G.J., Gregory, W.M., Davies, F.E., Bell, S.E., Szubert, A.J., Brown, J.M., et al. (2012) The Role of Maintenance Thalidomide Therapy in Multiple Myeloma: MRC Myeloma IX Results and Meta-Analysis. Blood, 119, 7-15. https://doi.org/10.1182/blood-2011-06-357038

[14] Holstein, S.A., Tong, H. and Hohl, R.J. (2010) Differential Activities of Thalidomide and Isoprenoid Biosynthetic Pathway Inhibitors in Multiple Myeloma Cells. Leukemia Research, 34, 344-351. https://doi.org/10.1016/j.leukres.2009.06.035

[15] Hideshima, T., Chauhan, D., Shima, Y., Raje, N., Davies, F.E., Tai, Y.T., et al. (2000) Thalidomide and Its Analogs Overcome Drug Resistance of Human Multiple Myeloma Cells to Conventional Therapy. Blood, 96, 2943-2950.

[16] Bartlett, J.B., Dredge, K. and Dalgleish, A.G. (2004) The Evolution of Thalidomide and Its IMiD Derivatives as Anticancer Agents. Nature Reviews Cancer, 4, 314-322. https://doi.org/10.1038/nrc1323

[17] Hayashi, T., Hideshima, T., Akiyama, M., Podar, K., Yasui, H., Raje, N., et al. (2005) Molecular Mechanisms Whereby Immunomodulatory Drugs Activate Natural Killer Cells: Clinical Application. British Journal of Haematology, 128, 192-203. https://doi.org/10.1111/j.1365-2141.2004.05286.x

[18] Cavo, M.I., Zamagni, E., Tosi, P., Cellini, C., Cangini, D., Tacchetti, P.A., et al. (2004) First-Line Therapy with Thalidomide and Dexamethasone in Preparation for Autologous Stem Cell Transplantation for Multiple Myeloma. Haematologica, 89, 826-831.

[19] Hussein, M.A. (2006) Thromboembolism Risk Reduction in Multiple Myeloma Patients Treated with Immunomodulatory Drug Combinations. Thrombosis and Haemostasis, 95, 917-1051. https://doi.org/10.1160/th06-02-0080

[20] Farber, H.W. and Loscaizo, J. (2004) Pulmonary Arterial Hypertension. New England Journal of Medicine, 351, 1655-1665. https://doi.org/10.1056/NEJMra035488

[21] Hoeper, M.M., Bogaard, H.J., Condliffe, R., Frantz, R., Khanna, D., Kurzyna, M., et al. (2013) Definitions and Diagnosis of Pulmonary Hypertension. Journal of the American College of Cardiology, 62, D42-D50. https://doi.org/10.1016/j.jacc.2013.10.032

[22] Simonneau, G., Gatzoulis, M.A., Adatia, I., Celermajer, D., Denton, C., Ghofrani, A., et al. (2013) Updated Clinical Classification of Pulmonary Hypertension. Journal of the American College of Cardiology, 62, D34-D41. https://doi.org/10.1016/j.jacc.2013.10.029

[23] Lafaras, C., Mandala, E., Verrou, E., Platogiannis, D., Barbetakis, N., Bischiniotis, T., et al. (2008) Non-Thromboembolic Pulmonary Hypertension in Multiple Myeloma, after Thalidomide Treatment: A Pilot Study. Annals of Oncology, 19, 1765-1769. https://doi.org/10.1093/annonc/mdn287

[24] Hurtado, G.R. and García, R.M. (2013) [Pulmonary Hypertension in a Patient with Talidomide]. Farmacia hospitalaria: organo oficial de expresion cientifica de la Sociedad Espanola de Farmacia Hospitalaria, 37, 267-269. (In Spanish)

[25] International Myeloma Working Group (2003) Criteria for the Classification of Monoclonal Gammopathies, Multiple Myeloma and Related Disorders: A Report of the International Myeloma Working Group. British Journal of Haematology, 121, 749-757.

[26] Younis, T.H. (2003) Reversible Pulmonary Hypertension and Thalidomide Therapy for Multiple Myeloma. British Journal of Haematology, 121, 191-192. https://doi.org/10.1046/j.1365-2141.2003.04245_2.x

[27] Hattori, Y., Shimoda, M., Okamoto, S., Satoh, T., Kakimoto, T. and Ikeda, Y. (2005) Pul- 
monary Hypertension and Thalidomide Therapy in Multiple Myeloma. British Journal of Haematology, 128, 885-887. https://doi.org/10.1111/j.1365-2141.2005.05389.x

[28] Antonioli, E., Nozzoli, C., Gianfaldoni, G., Mannelli, F., Rossi, S., Betti, S., et al. (2005) Pulmonary Hypertension Related to Thalidomide Therapy in Refractory Multiple Myeloma. Annals of Oncology, 16, 1849-1850. https://doi.org/10.1093/annonc/mdi357

[29] Villa, A., Mazzola, A.A., Ghio, S., Martinoli, E. and Marino, P. (2011) Reversible Pulmonary Hypertension Related to Thalidomide Treatment for Multiple Myeloma. Case Reports in Oncology, 4, 487-489. https://doi.org/10.1159/000333016

[30] Tamura, S., Koyama, A., Shiotani, C., Kurihara, T., Nishikawa, A., Okamoto, Y., et al. (2014) Successful Bortezomib/Dexamethasone Induction Therapy with Lenalidomide in an Elderly Patient with Primary Plasma Cell Leukemia Complicated by Renal Failure and Pulmonary Hypertension. Internal Medicine, 53, 1171-1175.

https://doi.org/10.2169/internalmedicine.53.1672

[31] Krishnan, U., Mark, T.M., Niesvizky, R. and Sobol, I. (2015) Pulmonary Hypertension Complicating Multiple Myeloma. Pulmonary Circulation, 5, 590-597.

https://doi.org/10.1086/682430

\section{Submit or recommend next manuscript to SCIRP and we will provide best service} for you:

Accepting pre-submission inquiries through Email, Facebook, LinkedIn, Twitter, etc.

A wide selection of journals (inclusive of 9 subjects, more than 200 journals)

Providing 24-hour high-quality service

User-friendly online submission system

Fair and swift peer-review system

Efficient typesetting and proofreading procedure

Display of the result of downloads and visits, as well as the number of cited articles

Maximum dissemination of your research work

Submit your manuscript at: http://papersubmission.scirp.org/

Or contact jet@scirp.org 